\title{
PERANCANGAN DAN PEMBUATAN SISTEM INFORMASI PEMESANAN PIGURA ONLINE
}

\author{
Yudho Yudhanto \\ Fakultas MIPA, Program Studi D3 Teknik Informatika \\ Universitas Negeri Sebelas Maret \\ Email: yuda@mipa.uns.ac.id \\ Ahmad Miftakul Qoironi \\ Fakultas MIPA, Program Studi D3 Teknik Informatika \\ Universitas Negeri Sebelas Maret \\ Email: qoironi@gmail.com
}

\begin{abstract}
ABSTRAK
Selama ini sistem penjualan masih mengandalkan media interaksi dengan konsumen secara langsung dan masih berpusat pada lokasi tertentu.Selain itu konsumen seringkali kesulit untuk mengakses berbagai informasi tentang produk, informasi harga terbaru, media promosi terbatas dan biaya operasi yang semakin meningkat. Dengan pembuatan Sistem Informasi Pemesanan Pigura online berbasis web ini mampu mengatasi hal tersebut. Pembuatan aplikasinya menggunakan model Framework Codeigniter 3. Sistem ini dikembangkan dengan menggunakan sejumlah aplikasi lain yaitu notepad ++, Dreamweaver, PHP dan CSS, javascript. Kemudian menggunakan tokopigura.biptek.id untuk menjalankan PhpMyAdminnya sebagai database server dan web browser. Selanjutnya merancang arsitektur websitenya. Sistem informasi Pemesanan Pigura online berbasis web ini sebagai sarana untuk memperluas dan mempermudah pelayanan sehingga dapat lebih efektif dan effesien bagi pelanggan yang berbelanja melalui web toko pigura. Didalam toko toko pigura terdapat beberapa kemudahan terutama dalam web ini bergerak di bidang penjualann pigura dari mulai model sederhana sampai model rumit, aplikasi ini memudahkan pembeli mencari pigura yang di inginkannya melalui sistem informasi pemesanan pigura online ini. Sistem iniformasi pemesanan pigura online ini secara signifikan lebih diminati karena proses bisnisnya lebih dinamis dan interaktif serta memiliki pola diferensiasi yang jelas untuk semua kalangan masyarakat.
\end{abstract}

Kata kunci: Sistem Informasi, Pemesanan Pigura, Javascript, CodeIgniter.

\section{ABSTRACT}

During this sales system still relies on media interaction with consumers directly and is still centered on the location tertentu. Selain that consumers often kesulit to access a variety of information about the product, the latest price information, media promotion is limited and operating costs are increasing. With the creation of Information Systems Web-based Booking online Pigura is able to overcome it. Making its application using CodeIgniter Framework models 3. The system was developed using a number of other applications that notepad ++, Dreamweaver, PHP and CSS, javascript. Then using tokopigura.biptek.id to run PhpMyAdminnya as a database server and web browser. Furthermore, designing the architecture of the website. Booking information system is a web-based online picture frame as a means to expand and facilitate service so that it can more effectively and effesien to customers who shop via the web store frames. Within the frame stores are some convenience especially in this website is engaged in penjualann frames ranging from simple models to complex models, this application allows shoppers look for frames that wanted it through the system frame ordering information online. Iniformasi online booking system frame is significantly more desirable because its business processes more dynamic and interactive as well as having a clear differentiation pattern for all societies.

Keywords: Information Systems, Booking Frames, Javascript, CodeIgniter. 


\section{PENDAHULUAN}

Informasi merupakan suatu hal yang sangat dibutuhkan didalam suatu organisasi ataupun instansi. Informasi juga merupakan kebutuhan bagi manajemen didalam pengambilan keputusan. Dengan dukungan ilmu pengetahuan khususnya dibidang Teknologi maka dibutuhkannya sebuah revolusi publikasi dalam membuka jangkauan informasi yang lebih luas untuk menyampaikan berbagai informasi salah satunya adalah melalui sebuah website. Didalam website kita bisa memberikan informasi apa saja yang ingin kita sampaikan, didalam bisnis maka kita akan menginformasikan produk yang akan kita jual.

\section{METODOLOGI PENELITIAN}

Metode penelitian yang digunakan untuk menyelesaikan penelitian ini adalah waterfall. Waterfall adalah model pengembangan sistem yang menjadi dasar atau awal untuk model pengembangan sistem lainnya ${ }^{[5]}$. Alur yang dilakukan adalah seperti gambar 1 berikut ini :

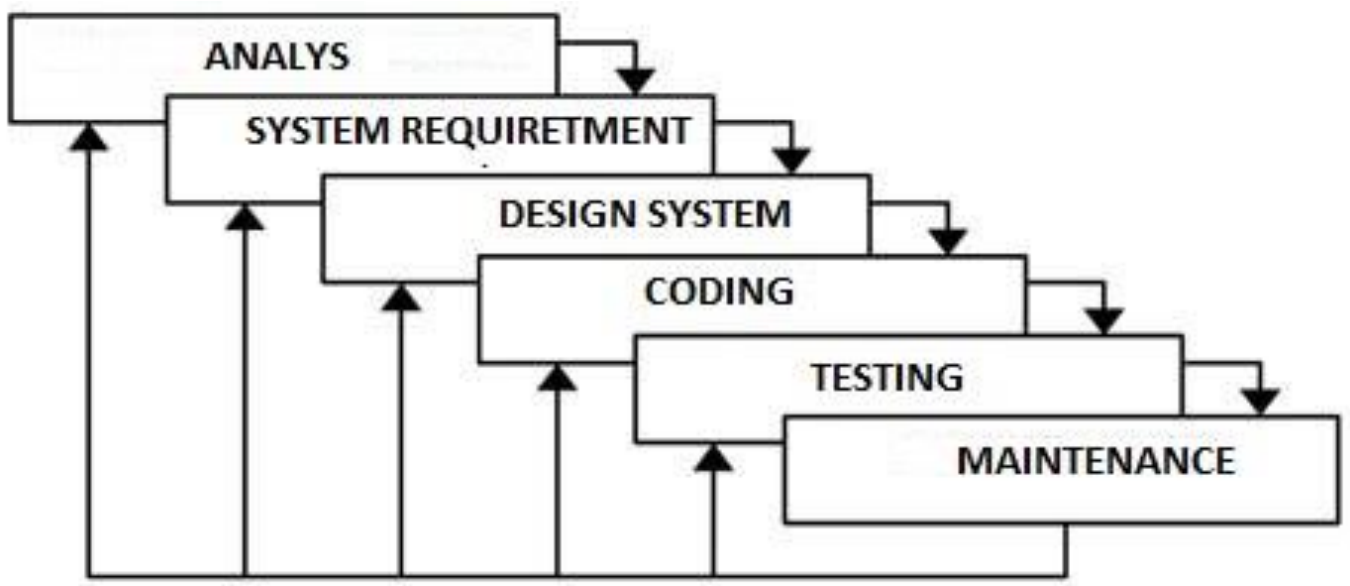

Gbr 1. Waterfall Models

Kemudian untuk detail pelaksanaannya dibagai dalam beberapa tahap yakni seperti berikut ini

\subsection{Studi Pustaka}

Studi pustaka adalah metode pengumpulan data dengan membaca buku atau literatur - literatur yang berhubungan dengan permasalahan yang dijadikan objek dalam penelitian.

2.2. Analisis kebutuhan

Penulis mengidentifikasi kebutuhan sistem dan garis besar aplikasi yang akan dibuat.

2.3. Melakukan perancangan

Penulis melakukan perancangan basis data dan tampilan user interface yang nantinya akan diimplementasikan kedalam sistem.

\subsection{Pengkodean Sistem}

Rancangan yang telah dibuat diterjemahkan dalam bentuk bahasa pemrograman yang sesuai, disini aplikasi menggunakan bahasa PHP.

2.5. Menguji Sistem

Pengujian dilakukan setelah aplikasi sudah siap dipakai. Pengujian menggunakan blackbox. 


\section{HASIL DAN PEMBAHASAN}

\subsection{Proses Bisnis Aplikasi}

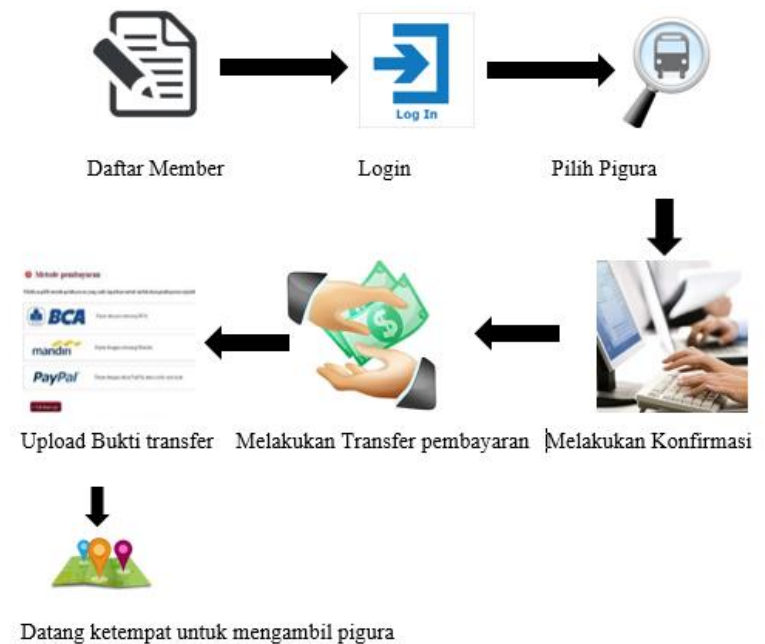

Gbr.2 Alur Proses Bisnis Aplikasi

Berdasar gambar 2 dijelaksan bahwa Perancangan dan pembuatan aplikasi Sistem Informasi Pemesanan Pigura Online ini menyediakan sistem pembelian yang dapat dilakukan via web. User yang ingin membeli pigura harus terlebih dahulu menjadi member. Kemudian login sebagai member lalu memlih pigura yang akan dibeli setelah itu melakukan konfirmasi, setelah pembelian di verifikasi oleh admin member diharuskan melakukan pembayaran melalui transfer bank yang telah tertera, setelah itu member menunggu di sms pemberitahuan untuk Datang ke toko pigura untuk mengambil pigura yang telah jadi.

\subsection{Use Case}

Use Case Diagram merupakan pemodelan untuk menggambarkan kelakuan (behavior) sistem yang akan dibuat ${ }^{[6]}$. Use Case Diagram pada aplikasi ini dapat dilihat pada gambar 3. 


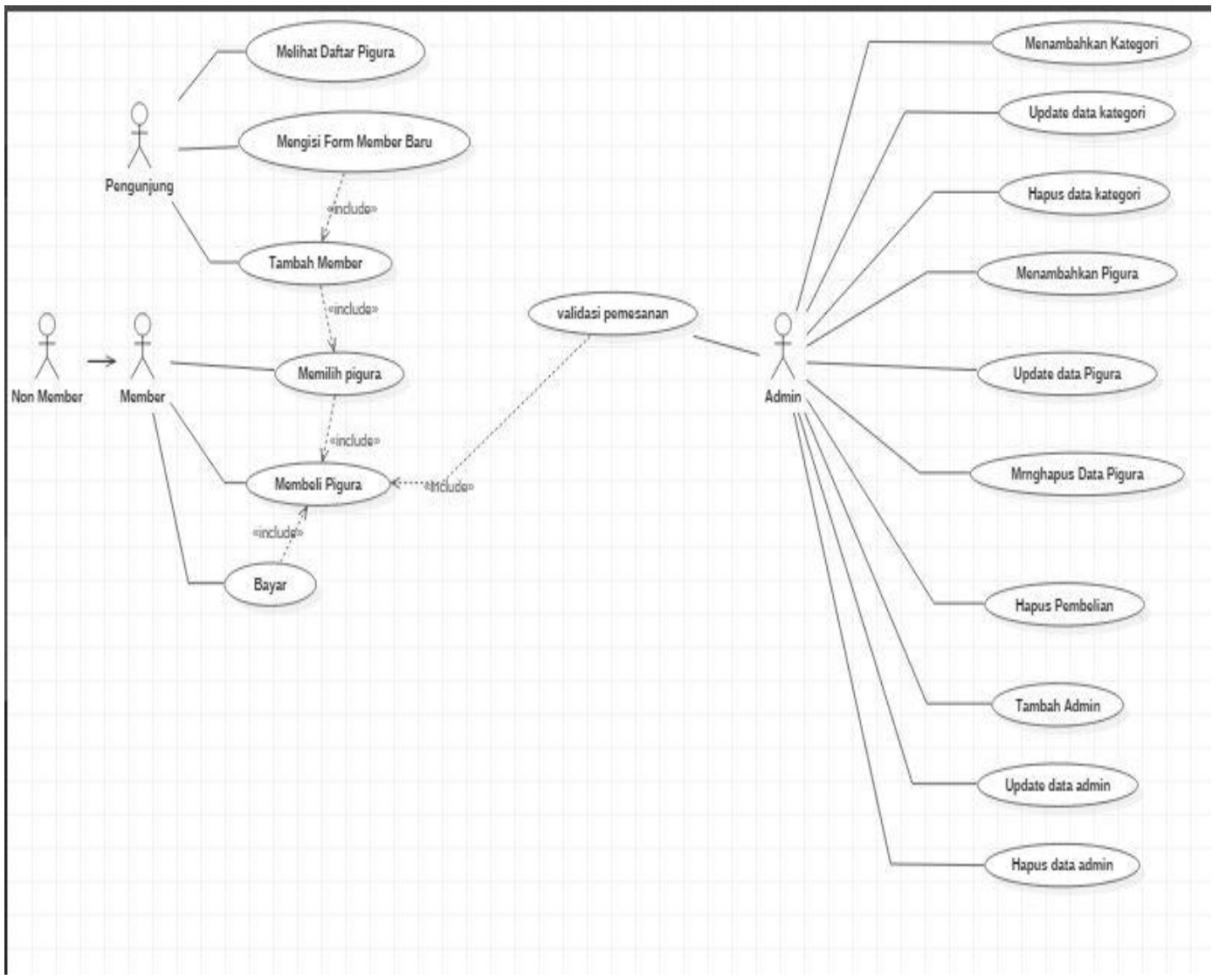

Gbr.3 Use Case Aplikasi Pemesanan Pigura Online

Pada use case diagram gambar 3 terdapat 3 aktor. Aktor tersebut adalah admin, Pengunjung non member dan member. Admin adalah user yang bertugas mengelola informasi yang akan ditampilkan pada web pemesanan pigura online, sedangkan pengunjung adalah user yang melihat informasi web sedangkan Member adalah orang yang dapat melihat isi web dan dapat melakukan transaksi pembelian pigura.

\subsection{ERD}

Entity Relationship Diagram (selanjutnya akan ditulis ERD) adalah suatu model untuk menjelaskan hubungan antar data dalam basis data berdasarkan objek - objek dasar data yang mempunyai hubungan antar relasi ${ }^{[7]}$. Dari proses identifikasi aktor dalam use case, maka bisa dibuatlah ERD (Entity Relationship Diagram) seperti yang terlihat dalam gambar 4. 


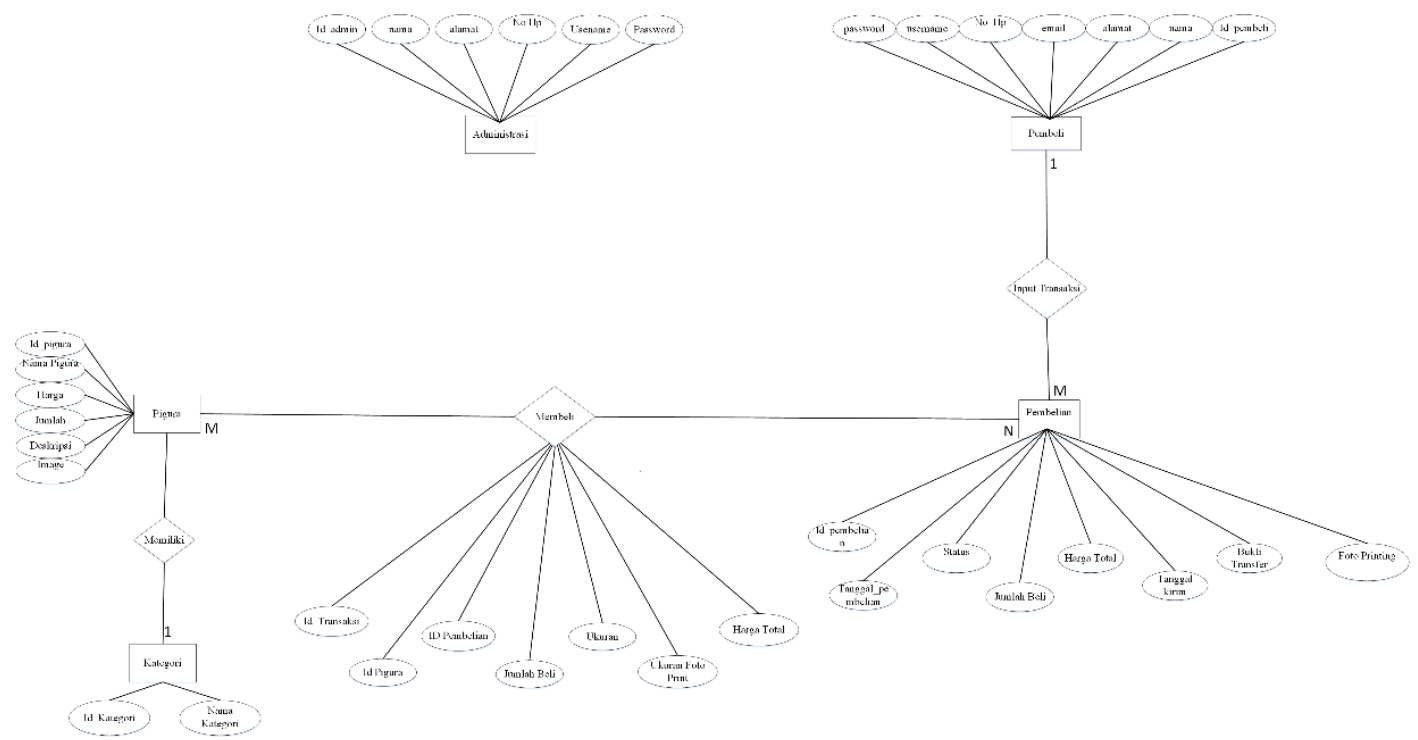

Gbr.4 ERD Entity Relationship Diagram (ERD) hubungan antar tabel Sistem Informasi Pemesanan Pigura Online berbasis web

\subsection{Relasi Tabel}

Relasi antar tabel menjelaskan hubungan tabel satu dengan tabel yang lainnya apakah one to one, one to many, atau many to many ${ }^{[8]}$. Dari proses identifikasi ERD, maka dapat dibuatlah relasi tabel seperti yang terlihat pada gambar 5 .

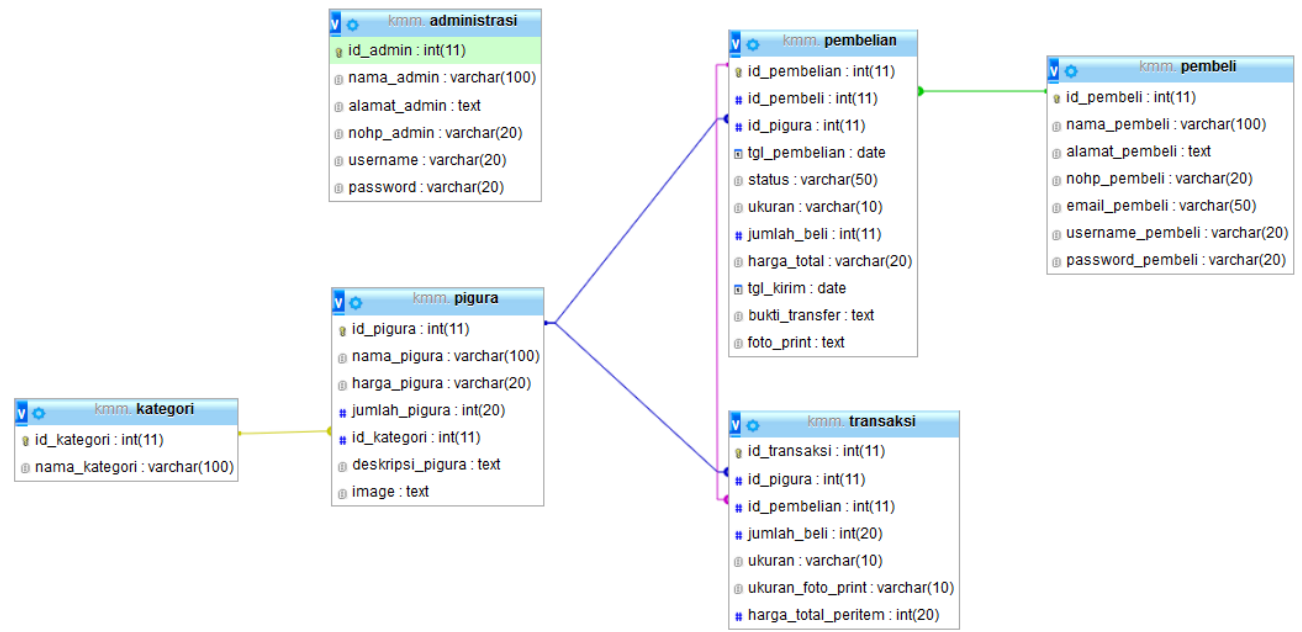

Gbr.5 Relasi Antar Tabel Sistem Informasi Pemesanan Pigura Online 


\subsection{User Interface}

User interface Sistem Informasi Pemesanan Pigura Online dibedakan menjadi tiga bagian utama sesuai dengan level user yakni admin, pengunjung/ non member, dan member. Beberapa rancangan dan implementasi user interface dapat dilihat dalam gambar 6, 7, 8, 9, 10, 11 dan gambar 12 , seperti dibawah ini.

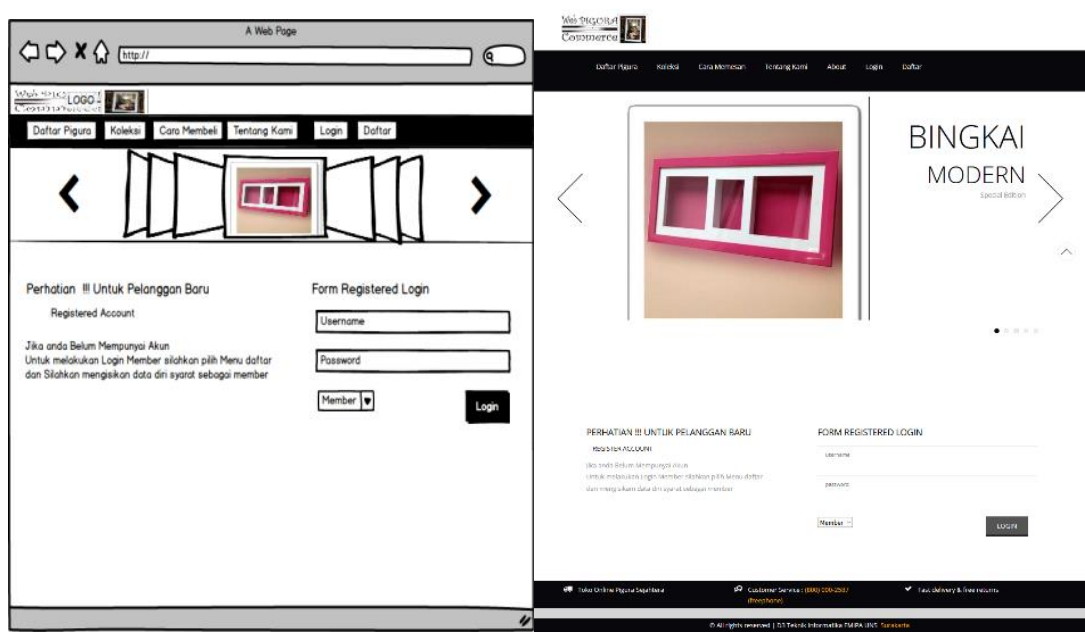

Gbr.6. Rancangan Halaman Login dan Implementasi Halaman Login

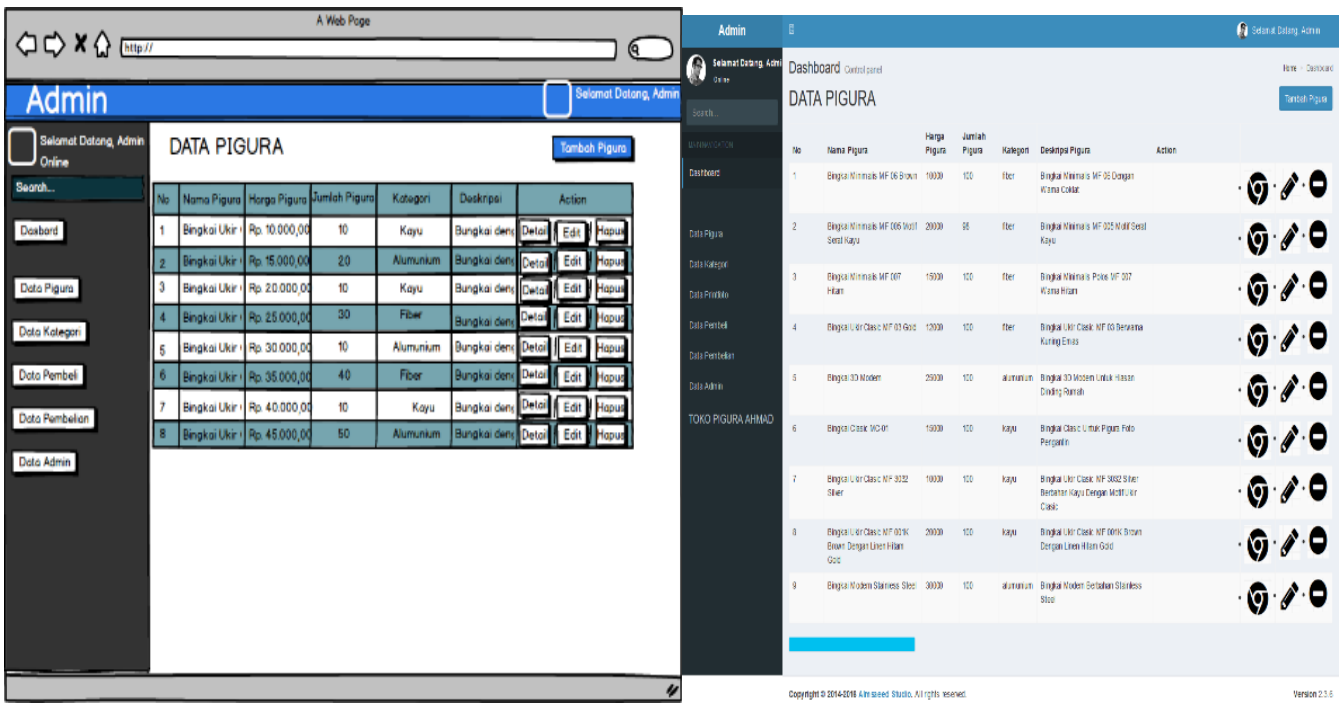

Gbr.7. Rancangan Halaman Dashboard dan Implementasi Halaman Dashboard Administrator 

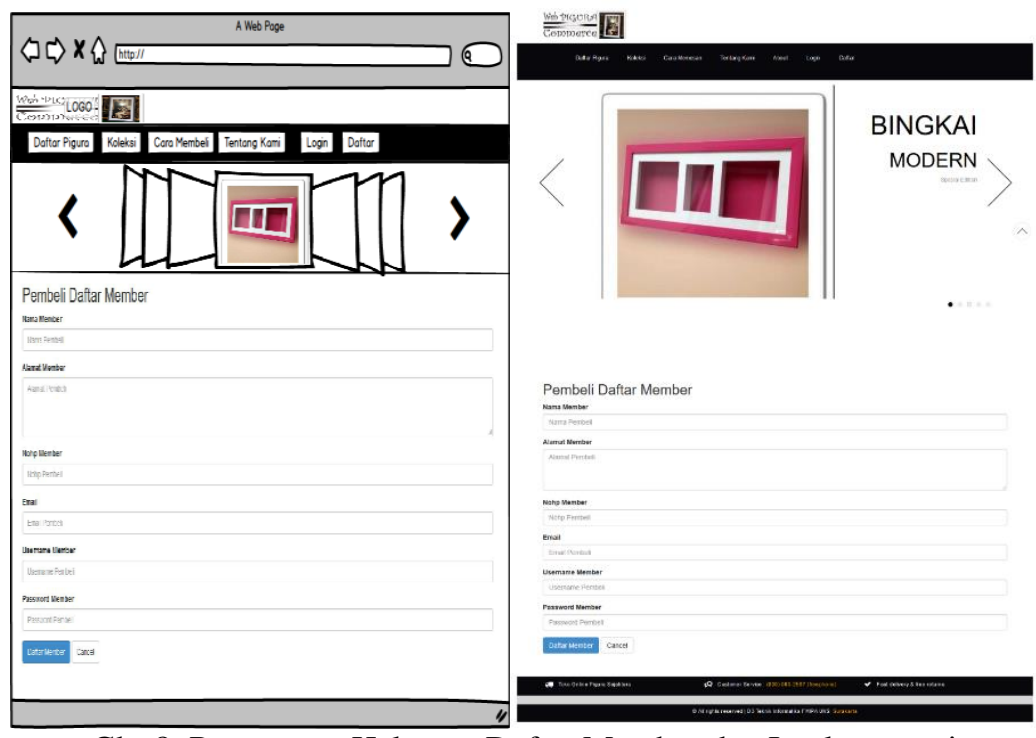

Gbr.8. Rancangan Halaman Daftar Member dan Implementasi

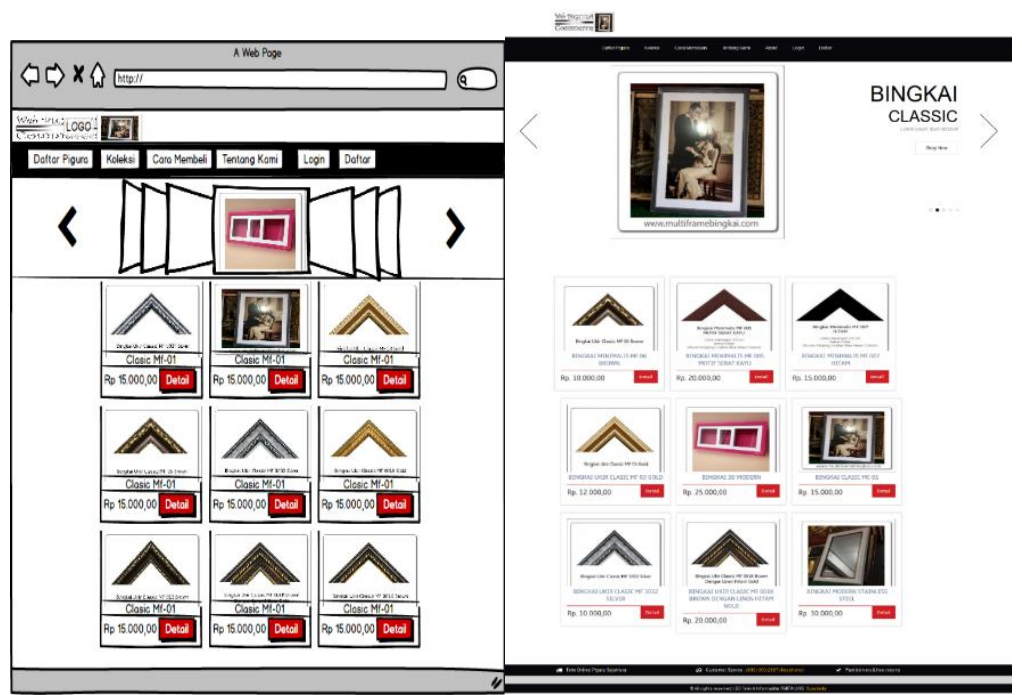

Gbr.9. Rancangan Halaman Depan User Pengunjung dan Implementasi 


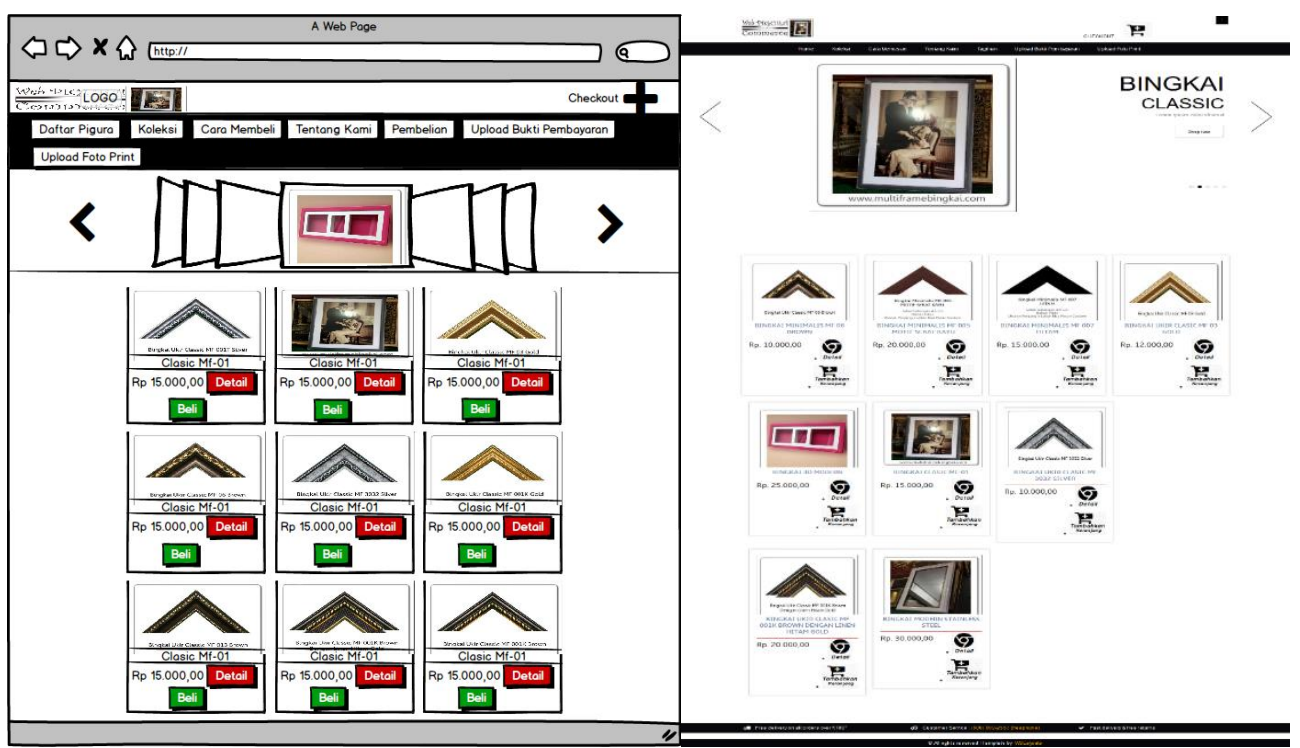

Gbr.10. Rancangan Halaman Home Member dan Implementasi

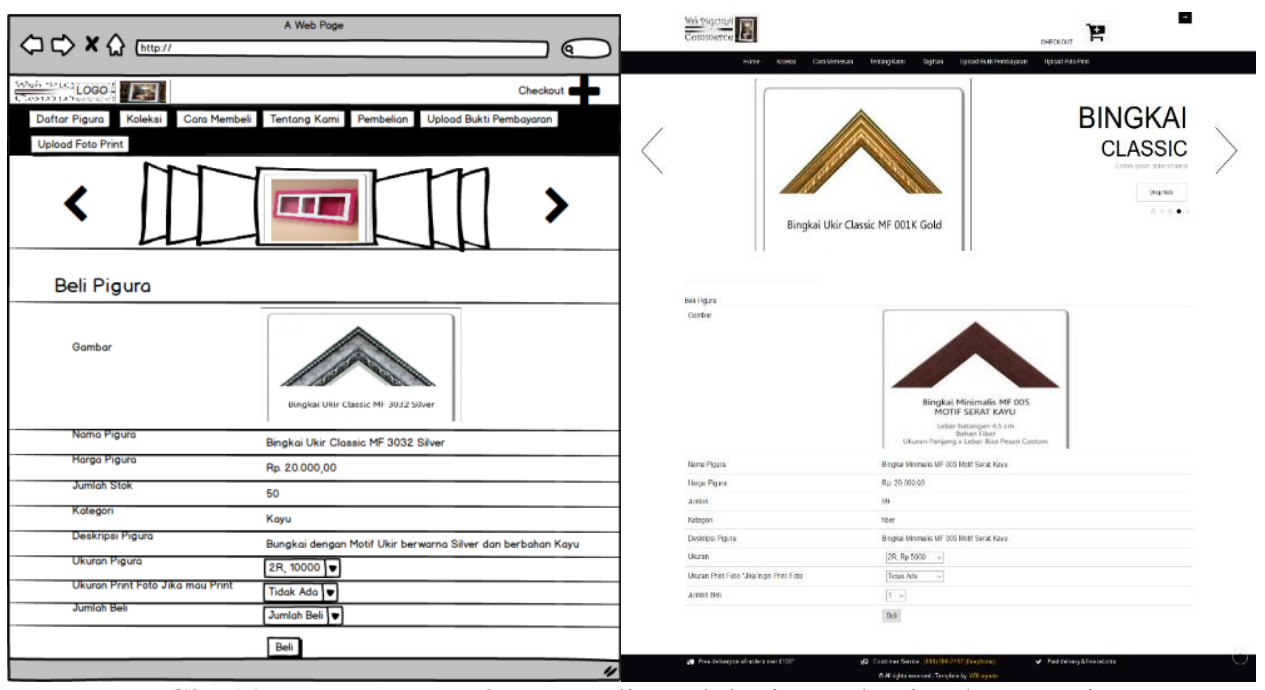

Gbr.11. Rancangan Halaman Beli Produk pigura dan implementasi 


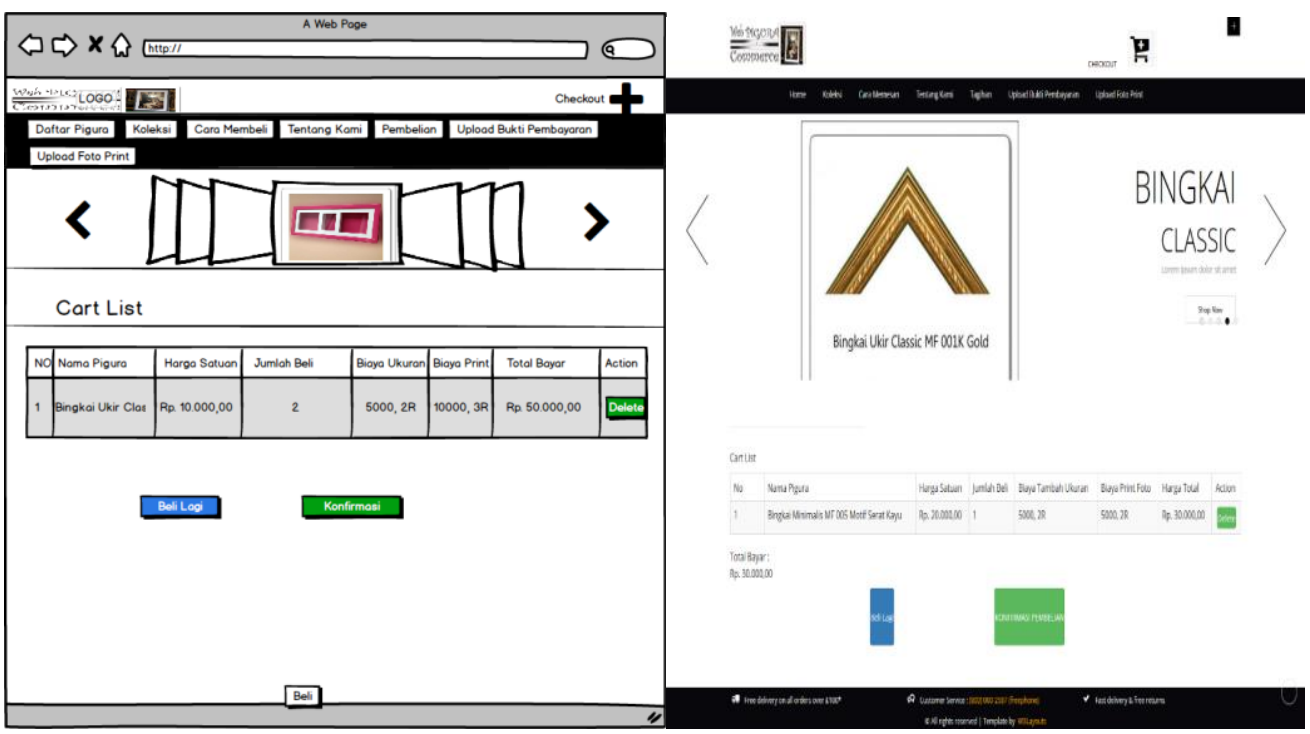

Gbr.12. Rancangan Halaman Konfirmasi dan Implementasi

\subsection{Pengujian}

Pengujian sistem dilakukan dengan metode blackbox testing yaitu pengujian yang dilakukan dari segi spesifikasi fungsional tanpa menguji desain kode program ${ }^{[9]}$. Berikut ini adalah beberapa pengujian pada gambar 13 dan 14 dibawah ini.

\begin{tabular}{|c|c|c|c|c|c|}
\hline No & \begin{tabular}{|l|} 
Skenario \\
Pengujian
\end{tabular} & Masukkan & \begin{tabular}{|l|l|} 
Hasil yang \\
diharapkan
\end{tabular} & \begin{tabular}{|l|} 
Hasil \\
pengujian
\end{tabular} & Kesimpulan \\
\hline 1 & \begin{tabular}{|l|} 
Mengosongkan \\
Semua Field \\
input pada form \\
login, kemudian \\
menekan tombol \\
login
\end{tabular} & $\begin{array}{l}\text { Username } \\
\text { - } \\
\text { Pasanvord } i \text { i }\end{array}$ & \begin{tabular}{|l|} 
Sistem Menolak \\
dan \\
memberitahukan \\
User Tidak \\
Ditemukan
\end{tabular} & \begin{tabular}{|l|} 
Sesuai \\
harapan
\end{tabular} & [ 1 mand Tidak \\
\hline 2 & \begin{tabular}{|l|} 
Mengisikan \\
Username benar \\
dan password \\
salah \\
mememudian \\
menan tombol \\
login
\end{tabular} & $\begin{array}{l}\text { Username } \\
\text { (Usemame } \\
\text { Benar) } \\
\text { Bassyord i } \\
\text { (salah) }\end{array}$ & $\begin{array}{l}\text { Sistem Menolak } \\
\text { dan } \\
\text { memberitahukan } \\
\text { Password salah }\end{array}$ & $\begin{array}{l}\text { Sesuai } \\
\text { harapan }\end{array}$ & [ $\begin{array}{l}\text { and Tidak } \\
\text { Berhasil }\end{array}$ \\
\hline 3 & \begin{tabular}{|l|} 
Mengisikan \\
Username benar \\
dan password \\
benar kemudian \\
menekan tombol \\
login
\end{tabular} & \begin{tabular}{|l|} 
Username i \\
(Usemame \\
Benar) \\
Bassyword. \\
(benar)
\end{tabular} & 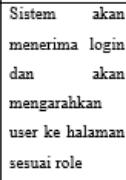 & \begin{tabular}{|l|} 
Sesuai \\
harapan
\end{tabular} & $\begin{array}{l}\text { [ and Tidak } \\
\text { Berhasil }\end{array}$ \\
\hline
\end{tabular}

Gbr.13. Pengujian bagian Halaman Login 


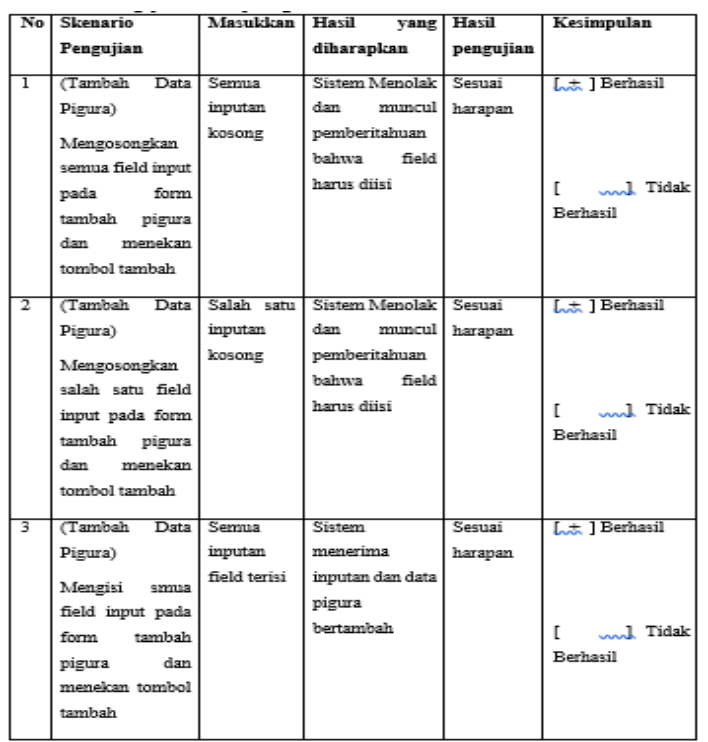

Gbr.14. Pengujian Bagian Pengelolaan Pigura

\section{KESIMPULAN}

Kesimpulan dari perancangan dan pembuatan aplikasi Sistem Informasi Pemesanan Pigura Online berbasis web adalah sebagai berikut:

1. Aplikasi Sistem Informasi Pemesanan Pigura Online berbasis web telah selesai dibuat yang memfasilitasi tiga aktor yaitu User/Tamu hanya bisa melihat daftar pigura, Member Bisa melakukan login dan melakukan aktivitas transaksi pembelian pigura, dan Admin untuk mengelola data master dan mengelola Pembelian transaksi.

2. Aplikasi Sistem Informasi Pemesanan Pigura Online berbasis web telah selesai dibuat dan diuji dengan menggunakan black box yang menghasilkan kesimpulan berhasil sesuai dengan apa yang diharapkan.

\section{DAFTAR PUSTAKA}

[1] Laudon \& Kenneth, 2005. Sistem Informasi Manajemen, Mengelola Perusahaan Digital. Yogyakarta: Andi.

[2] Pratama, A. N. W., 2010. CodeIgniter : Cara Mudah Membangun Aplikasi PHP. Jakarta: mediakita

[3] Syafii, M., 2005. Panduan Membuat Aplikasi Database dengan PHP 5 MySQL PostgreSQL Oracle. Yogyakarta: Andi

[4] Sholiq. 2006. Pemodelan Sistem Informasi Berorientasi Obyek dengan UML. Yogyakarta: Graha Ilmu

[5] Khurana, Gourav \& Gupta, Sachin., 2012. Study \& Comparisonof Software Development Life Cycle Models. iJREAS, 2(2).

[6] Agung Yulianto, A., Gartina, I., Astuti, Ri., Dewi, S., Komala Saro, S., \& Witanti,W. 2009. Analisis Dan Desain Sistem Informasi. (A. Hendraputra, Ed.). Bandung: Politeknik Telkom.

[7] Sutanta, E., 2004. Sistem Basis Data. Yogyakarta: Graha Ilmu

[8] Buyens, Jim. 2001. Web Database Development. Jakarta: Elex Media Komputindo.

[9] Black, Rex. 2009. Managing The Testing Process. Washington: Microsoft Press. 